DOI: http://doi.org/10.21698/simi.2017.0017

\title{
ASSESSMENT OF WATER AND SEDIMENT CHARACTERISTICS OF THE NORTHERN DANUBE DELTA LAKES - MATIT,A, BABINA AND MERHEI, ROMANIA
}

\author{
Irina Catianis ${ }^{1}$, Dan Secrieru ${ }^{2}$, Albert Scrieciu ${ }^{1}$, Dumitru Grosu ${ }^{1}$, Iulian Pojar ${ }^{1}$, \\ Ana Bianca Pavel ${ }^{2}$ \\ ${ }^{1}$ National Research and Development Institute for Marine Geology and Geoecology - \\ GeoEcoMar, Bucharest, 23 - 25 Dimitrie Onciul, 024053, Romania, \\ irina.catianis@geoecomar.ro \\ ${ }^{2}$ National Research and Development Institute for Marine Geology and Geoecology - \\ GeoEcoMar, Constanta, 304 Mamaia Blvd, 90058 , Romania
}

\begin{abstract}
At the end of its course of $2857 \mathrm{~km}$ running to the Black Sea, the Danube River - the longest river in the European Union shapes a river delta, an exclusive area consisting of a complexity of water and land, numerous lakes, ponds, marshes and unique waterways. The Danube Delta, considered the Europe's largest wetlands, is included in Unesco's World Heritage list, due to its outstanding importance conferred by the many natural habitats with their specific characteristics and bio diversities, preserved in a near pristine state. Even though considerable conservation efforts have been made lately, the Danube Delta is still subject to threats due to both natural and anthropogenic stressors that may alter its ecosystems. This study aims to investigate the water and bed-sediment general characteristics of some lakes from the Matița - Merhei Depression located in the fluvial delta plain, to assess the current quality status of water and sediments. A significant number of water and sediment samples were collected from each lake in October 2016, for determination of water physicalchemical parameters, lithological components and some heavy metals - analysed in random bed-sediment samples. The investigation results show that the water environment-related indicators fluctuated in terms of sampling sites and generally agreed with the Romanian environmental quality criteria. Average lithological composition of the bed-sediments indicates an autochthonous source for the recent accumulation of sediments. Overall, the technophyllic heavy metal concentrations of the bed-sediments were below the limits of the quality criteria. The exceptions were represented by local values, incidentally exceeding the recommended limit.
\end{abstract}

Keywords: assessment, bed-sediments, environment, physical-chemical, surface water

\section{Introduction}

The Danube Delta is mainly located in Romania, with sectors in Ukraine. The delta is developed and elaborated at the Danube River mouth, by the division of the three river branches that flows into the Black Sea. The deltaic edifice is divided into three main depositional systems: the delta plain, the delta front, and the pro-delta.

The delta edifice integrates two main compartments: the upper fluvial delta plain located on the west side, and the lower fluvio-marine delta plain that is evolved on the east side, and up to the Black Sea coastline. These units are partitioned by the initial 


\section{INTERNATIONAL SYMPOSIUM "THE ENVIRONMENT AND THE INDUSTRY", SIMI 2017, PROCEEDINGS BOOK}

littoral ridge: Jibrieni-Letea-Răducu-Ceamurlia-Caraorman-Sărăturile-PerișorLupilor (Panin 1996). The importance of the Danube Delta as Europe's largest remaining natural wetland derives from inestimable habitats for wetland wildlife and biodiversity, so it was conferred a triple international protected area's statute Biosphere natural reserve (as part of the Man and Biosphere Programme), a World Wildlife Heritage Site accredited by UNESCO and a Wetland of International Importance (since 1990 as reported by Wetland Convention Ramsar). The Danube Delta acts as an environmental buffer zone between the Danube River and the Black Sea, filtrating the potential contaminants derived from changes as a result of uncontrolled past and current practices related to urban run-off and agricultural wastewater discharges at the upstream countries that influence the flow in the downstream region. To the same extent, the Danube Delta environment would be impinged by the ecological changes that occur in the Delta itself. As a result of these changes, it becomes essential to study the actual current quality status of its aquatic ecosystems. The lakes selected for this study, namely Matita, Babina and Merhei, belong to the Matita-Merhei Depression, one of the largest lake systems, which covers an area of 5700 ha (including 108 shallow lakes), being located in the fluvial Danube Delta plain. Matita (652 ha), Babina (338 ha) and Merhei (1057.5 ha) are the widest lakes from this depression (Gastescu et al. 2008). The purpose of this paper is the assessment of the physical-chemical characteristics of water and sediments from Matita, Babina and Merhei lakes.

\section{Materials and Methods}

\section{Study Area and Sampling Stations}

The Matita-Merhei Depression represents one of the largest lake systems in the Danube Delta being located between Chilia and Sulina arms, in the central region of the Letea fluvio-marine grind (Letea Island - sandy areas with dunes). The natural and artificial hydrographic network of inlets and canals is defined by Eracle, Lopatna, Dovnica, Raducu, Bogdaproste, Sulimanca and Rosca (Bondar et al. 2001). These lakes (i.e., Matita, Babina and Merhei) belong to the category of lakes with a large aquatorium and relative active changes of waters, including a secondary hydrographic network, too. The great distance from the lakes to the Danube River arms led to the poor water circulation of these lakes. Even if they are geographically closely located one to each other, the Babina Lake, for instance, is situated in an area with a relatively active circulation of water, in comparison to Matita and Merhei lakes that are situated in an area affected by poor water circulation, specifically during the summer and autumn months, due to the low water levels (Gastescu et al. 2008). To some extent, the poor water circulation is also influenced by the siltation, a specific phenomenon that occurred within deltaic areas, and the abundant aquatic vegetation that both reduce and determines an impediment to some specific natural function as the water circulation of these lakes. Anywise, there are several waterways that provide the inputs and outputs into/from the Matita-Merhei complex:

Lopatna Stream, Eracle Canal, Radacinoasele Canal (NW of Babina L.), Stipoc Canal (W of Babina L.), Canal to the Miazazi Lake (S of Matita L.), Lopatna Canal (N of Matita L.) and the Suez Canal (NE of Matita L.). 


\section{INTERNATIONAL SYMPOSIUM "THE ENVIRONMENT AND THE INDUSTRY", SIMI 2017, PROCEEDINGS BOOK}

Sample collection and analysis

The field measurement activities were performed aboard the"Istros" RV owned by the National Research and Development Institute for Marine Geology and Geoecology - GeoEcoMar, Romania. For the purpose of this study, 49 sampling sites (Figure 1) monitored during October 2016 were selected. A part of water quality variables were measured in situ at the sampling points (i.e., depth, temperature, transparency, dissolved oxygen, $\mathrm{pH}$, electrical conductivity etc.). After collection, the remaining ex situ water variables (i.e., total dissolved solids, turbidity, nitrates, nitrites, orthophosphates, sulphates etc.), were promptly measured and analysed with portable sensors -WTW Multiline P4 Multiparameter, HACH 2100Q, HACH 5000 $\mathrm{UV}-\mathrm{V}$ is - Spectrophotometer. The water and sediment environment-related indicators were mainly related to the Romanian environmental quality criteria (Order 161/2006, STAS 6323 - 88, Order 756/1997), but has also consulted other international environmental standards.

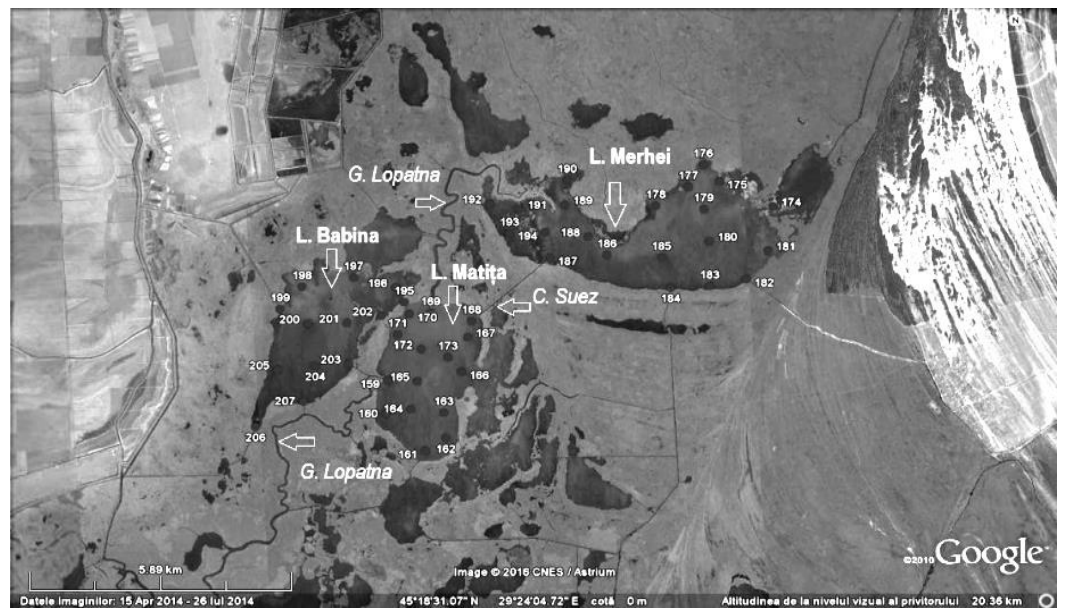

Figure 1. Map of the sampling sites of the study area

For sampling the bed-sediments (the upper layer $-0-20 \mathrm{~cm}$ of the sediment-water interface) was used a Van-Veen grab sampler. Determination of dry matter residue $(\% \mathrm{DM})$ and water content (\% WC) were performed gravimetrically by the classical laboratory Loss On Drying (LOD) method. Loss On Ignition (LOI) analysis was used to assess the total organic content (\% TOM), carbonates (\% CAR) and siliciclastic fraction (\% SIL) of bed-sediment samples (Dean 1974; Heiri et al. 2001; Santisteban et al. 2004). The distribution of some selected major, minor and trace elements $\left(\mathrm{Fe}_{2} \mathrm{O}_{3}\right.$, $\mathrm{TiO}_{2}, \mathrm{Rb}, \mathrm{Sr}, \mathrm{Zr}$ and $\mathrm{V}$ ) was estimated in random bed-sediment samples by X-ray fluorescence spectrometry on a VRA - 30 XRF sequential spectrometer, fitted with an X-ray tube with chromium anode, directly on compacted powders. An analyser crystal LiF 200 was utilized to select the characteristic wavelengths, measurements being done with a $\mathrm{Na}(\mathrm{Tl}) \mathrm{J}$ scintillation detector. Titration methods were applied to determine CaCO3 (Black 1965) and TOC - total organic carbon (Gaudette et al. 1974). $\mathrm{MnO}, \mathrm{Cr}, \mathrm{Zn}, \mathrm{Ni}, \mathrm{Co}, \mathrm{Cu}$ and $\mathrm{Pb}$ were tested by flame atomic absorption spectrometry 


\section{INTERNATIONAL SYMPOSIUM "THE ENVIRONMENT AND THE INDUSTRY", SIMI 2017, PROCEEDINGS BOOK}

and $\mathrm{Cd}$ by electro-thermal atomic absorption spectrometry on a Pye Unicam SOLAAR 939E double beam absorption spectrophotometer with deuterium lamp background correction.

\section{Results and Discussion}

\section{Water characteristics}

The physical and chemical characteristics of water samples from three lakes of the Matita-Merhei unit are shown in Table 1. The investigation results show that the water environment-related indicators fluctuated in terms of sampling sites and generally agreed with the Romanian or international environmental quality criteria. Water variables did not show significant variation among the three lakes. For example, the thermal regime and water acidification present normal values. The water temperature exhibited normal values that were consistent with seasonal climate variations encountered during the wet season. So, the mean value was quite similar in the three lakes as Matita $\left(10.83^{\circ} \mathrm{C}\right)$, Merhei $\left(9.54^{\circ} \mathrm{C}\right)$ and Babina $\left(9.65^{\circ} \mathrm{C}\right)$. The $\mathrm{pH}$ values in surface water varied from neutral to slightly alkaline. The dissolved oxygen content concentration displays the highest mean value $(8.85 \mathrm{mg} / \mathrm{l})$ in Matita Lake, while the lowest mean value was noticed in Babina Lake $(7.59 \mathrm{mg} / \mathrm{L})$. Some variations were noticed in nutrient regimes of investigated lakes.

For instance, the $\mathrm{N}_{-} \mathrm{NO}_{3}{ }^{-}$concentration in all investigated surface water samples show values below the limit values established for Class I (Order 161/2006). Instead, some water samples gathered from all lakes showed that the $\mathrm{N}_{-} \mathrm{NO}_{2}^{-}$concentration exceeding the limit value settled for Class I and II according to limit values (Order 161/2006). The same tendency is also valid for $\mathrm{P}_{-} \mathrm{PO}_{4}{ }^{3-}$, observing elevated values in most of the samples exceeding the limit value settled for all quality classes as reported by environmental reference (Order 161/2006). Electrical Conductivity (EC) mean value increases from Matita Lake to Babina Lake and ranged between $388.27 \mu \mathrm{S} / \mathrm{cm}$ to $489.31 \mu \mathrm{S} / \mathrm{cm}$. TDS indicator exhibited the highest mean value $(244.65 \mathrm{mg} / \mathrm{L})$ in Babina Lake, while the lowest mean value was recorded in Matita Lake (194.13 $\mathrm{mg} / \mathrm{L})$. For $\mathrm{SO}_{4}{ }^{2-}$ were recorded values situated below the limit values established for Class I (Order 161/2006). The turbidity indicated values in the range of $1.55 \mathrm{mg} / \mathrm{l}$ and $13.3 \mathrm{mg} / \mathrm{l}$, exhibiting the highest mean value $(5.94 \mathrm{mg} / \mathrm{l})$ in Matita Lake, while the lowest mean value was recorded in Merhei Lake (3,65 mg/l). The Total Suspended Substances (TSS) levels in tested samples were in line with the maximum permissible level for TSS in the freshwater environment. The $\mathrm{SiO}_{2}$ content recorded values in agreement with the range of variation in natural waters $(5-25 \mathrm{mg} / \mathrm{L})$.

\section{Sediment characteristics}

The physical and chemical characteristics of the bed-sediments collected from three lakes (Matita, Merhei and Babina) of the Danube Delta are shown in Table 2.

The lithological analyses as content based on the total organic matter content (\% TOM), the total carbonate content (\%CAR) and siliciclastic fraction (\% SIL) showed significant fluctuations among the three ecosystems. An overall assessment of the composition of lake sediments can be done according to the weight percentages TOM $(\%)$, CAR (\%) and SIL (\%), figured by the total weight of dry sediment (G. van der Veer 2006). 
Table 1. The physical - chemical parameters of water characteristics collected from Matita, Merhei and Babina lakes

\begin{tabular}{|c|c|c|c|c|c|c|c|c|}
\hline \multirow{9}{*}{ 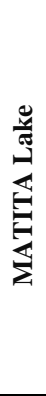 } & \multicolumn{8}{|c|}{ The physical-chemical parameters } \\
\hline & Value & $\begin{array}{c}\text { Temp. } \\
\left({ }^{\circ} \mathrm{C}\right)\end{array}$ & $\underset{\text { (units) }}{\mathbf{p H}}$ & $\begin{array}{c}\mathrm{O}_{2} \\
(\mathrm{mg} / \mathrm{l})\end{array}$ & $\begin{array}{c}\mathbf{O}_{2} \\
(\%)\end{array}$ & $\begin{array}{c}\mathrm{N}- \\
\mathrm{NO}_{2}^{-} \\
(\mathrm{mg} / \mathrm{l})\end{array}$ & $\begin{array}{c}\mathrm{N}- \\
\mathrm{NO}_{3}^{-} \\
(\mathrm{mg} / \mathrm{l})\end{array}$ & $\begin{array}{c}\mathrm{P}- \\
\mathrm{PO}_{4}{ }^{3-} \\
(\mathrm{mg} / \mathrm{l})\end{array}$ \\
\hline & $\min$ & 10.4 & 7,8 & 7,52 & 68 & 0,007 & 0,02 & 0,08 \\
\hline & $\max$ & 11.5 & 8,34 & 9,22 & 82,8 & 0,031 & 0,09 & 1,77 \\
\hline & mean & 10.83 & 8,09 & 8,85 & 79,03 & 0,018 & 0,04 & 0,96 \\
\hline & Value & $\begin{array}{c}\text { EC } \\
(\mu \mathrm{S} / \mathrm{cm})\end{array}$ & $\begin{array}{c}\text { TDS } \\
(\mathrm{mg} / \mathrm{l})\end{array}$ & $\begin{array}{l}\mathrm{SO}_{4}{ }^{2-} \\
(\mathrm{mg} / \mathrm{l})\end{array}$ & $\begin{array}{c}\text { Turb } \\
\text { (NTU) }\end{array}$ & $\begin{array}{c}\text { TSS } \\
(\mathrm{mg} / \mathrm{l})\end{array}$ & $\begin{array}{l}\text { VDS } \\
(\mathrm{m})\end{array}$ & $\begin{array}{c}\mathrm{SiO}_{2} \\
(\mathrm{mg} / \mathrm{l})\end{array}$ \\
\hline & $\min$ & 368 & 184 & 26 & 2,36 & 5 & 0,7 & 0,47 \\
\hline & $\max$ & 455 & 227,5 & 31 & 11,1 & 17 & 1,75 & 4,07 \\
\hline & mean & 388,27 & 194,13 & 28,67 & 5,94 & 11 & 1,14 & 2,54 \\
\hline \multirow{9}{*}{ 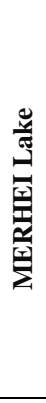 } & \multicolumn{8}{|c|}{ The physical-chemical parameters } \\
\hline & Value & $\begin{array}{c}\text { Temp. } \\
\left({ }^{\circ} \mathrm{C}\right)\end{array}$ & $\underset{\text { (units) }}{\mathbf{p H}}$ & $\begin{array}{c}\mathrm{O}_{2} \\
(\mathrm{mg} / \mathrm{l})\end{array}$ & $\begin{array}{c}\mathrm{O}_{2} \\
(\%)\end{array}$ & $\begin{array}{c}\mathrm{N}- \\
\mathrm{NO}_{2}^{-} \\
(\mathrm{mg} / \mathrm{l})\end{array}$ & $\begin{array}{c}\mathrm{N}- \\
\mathrm{NO}_{3}^{-} \\
(\mathrm{mg} / \mathrm{l})\end{array}$ & $\begin{array}{c}\mathrm{P}- \\
\mathrm{PO}_{4}{ }^{3-} \\
(\mathrm{mg} / \mathrm{l})\end{array}$ \\
\hline & $\min$ & 8,7 & 7,95 & 7,42 & 66,8 & 0,007 & 0,01 & 0,05 \\
\hline & $\max$ & 10,9 & 8,68 & 10,4 & 91,2 & 0,024 & 0,03 & 1,76 \\
\hline & mean & 9,54 & 8,43 & 8,83 & 76,13 & 0,017 & 0,02 & 0,67 \\
\hline & Value & $\begin{array}{c}\text { EC } \\
(\mu \mathrm{S} / \mathrm{cm})\end{array}$ & $\begin{array}{c}\text { TDS } \\
(\mathrm{mg} / \mathrm{l})\end{array}$ & $\begin{array}{l}\mathrm{SO}_{4}{ }^{2-} \\
(\mathrm{mg} / \mathrm{l})\end{array}$ & $\begin{array}{c}\text { Turb } \\
\text { (NTU) }\end{array}$ & $\begin{array}{c}\text { TSS } \\
(\mathrm{mg} / \mathrm{l})\end{array}$ & $\begin{array}{l}\text { VDS } \\
(\mathrm{m})\end{array}$ & $\begin{array}{c}\mathrm{SiO}_{2} \\
(\mathrm{mg} / \mathrm{l})\end{array}$ \\
\hline & $\min$ & 372 & 186 & 23 & 1,91 & 5 & 0,5 & 0,39 \\
\hline & $\max$ & 535 & 267,5 & 34 & 6,15 & 8 & 1,25 & 3,89 \\
\hline & mean & 439,71 & 219,86 & 28,25 & 3,65 & 6,14 & 0,85 & 1,72 \\
\hline \multirow{9}{*}{ 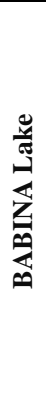 } & \multicolumn{8}{|c|}{ The physical-chemical parameters } \\
\hline & Value & $\begin{array}{c}\text { Temp. } \\
\left({ }^{\circ} \mathbf{C}\right)\end{array}$ & $\underset{\text { (units) }}{\mathbf{p H}}$ & $\begin{array}{c}\mathrm{O}_{2} \\
(\mathrm{mg} / \mathrm{l})\end{array}$ & $\begin{array}{c}\mathrm{O}_{2} \\
(\%)\end{array}$ & $\begin{array}{c}\mathrm{N}- \\
\mathrm{NO}_{2}^{-} \\
(\mathrm{mg} / \mathrm{l})\end{array}$ & $\begin{array}{c}\mathrm{N}- \\
\mathrm{NO}_{3}^{-} \\
(\mathrm{mg} / \mathrm{l})\end{array}$ & $\begin{array}{c}\mathrm{P}- \\
\mathrm{PO}_{4}{ }^{3-} \\
(\mathrm{mg} / \mathrm{l})\end{array}$ \\
\hline & $\min$ & 9,3 & 7,65 & 5,74 & 52,3 & 0,007 & 0,01 & 0,06 \\
\hline & $\max$ & 10,6 & 8,44 & 8,61 & 74,5 & 0,054 & 0,30 & 0,82 \\
\hline & mean & 9,65 & 8,15 & 7,59 & 66,09 & 0,023 & 0,08 & 0,21 \\
\hline & Value & $\begin{array}{c}\text { EC } \\
(\mu \mathrm{S} / \mathrm{cm})\end{array}$ & $\begin{array}{c}\text { TDS } \\
(\mathrm{mg} / \mathrm{l})\end{array}$ & $\begin{array}{l}\mathrm{SO}_{4}{ }^{2-} \\
(\mathrm{mg} / \mathrm{l})\end{array}$ & $\begin{array}{c}\text { Turb } \\
\text { (NTU) }\end{array}$ & $\begin{array}{c}\text { TSS } \\
(\mathrm{mg} / \mathrm{l})\end{array}$ & $\begin{array}{l}\text { VDS } \\
(\mathrm{m})\end{array}$ & $\begin{array}{c}\mathrm{SiO}_{2} \\
(\mathrm{mg} / \mathrm{l})\end{array}$ \\
\hline & $\min$ & 403 & 201,5 & 18 & 1,55 & 1 & 0,3 & 1,13 \\
\hline & $\max$ & 699 & 349,5 & 37 & 13,3 & 17 & 1,25 & 10,08 \\
\hline & mean & 489,31 & 244,65 & 31,13 & 5,03 & 6,38 & 0,80 & 3,24 \\
\hline
\end{tabular}

Also, an empirical classification of lake sediments based on the percentage of the carbonate content was taken into consideration (De Bakker \& Schelling 1989). Thereby, the TOM (\%) showed highest mean concentration, over $50 \%$ of the total weight of dry sediment, as in the Merhei Lake (84.27 \%) and Babina Lake (79.77\%), while the lowest mean value was noticed in Matita Lake $(62.48 \%)$.

Table 2. The physical - chemical parameters of water characteristics collected from Matita, Merhei and Babina lakes

\begin{tabular}{c|c|ccccc}
\hline \multirow{3}{*}{} & \multicolumn{5}{|c}{ Distribution of the main lithological parameters in bed-sediments } \\
\cline { 2 - 7 } & Value & TOM & CAR & SIL & WC & DM \\
& & $\%$ & $\mathbf{\%}$ & $\mathbf{\%}$ & $\mathbf{\%}$ & $\boldsymbol{\%}$ \\
\cline { 2 - 7 } & $\min$ & 30,86 & 7,89 & 9,60 & 23,53 & 28,69 \\
& $\max$ & 78,77 & 38,36 & 56,14 & 71,31 & 76,47 \\
& $\operatorname{mean}$ & 62,48 & 16,68 & 20,84 & 34,93 & 65,07 \\
\hline
\end{tabular}


INTERNATIONAL SYMPOSIUM "THE ENVIRONMENT AND THE INDUSTRY", SIMI 2017, PROCEEDINGS BOOK

\begin{tabular}{|c|c|c|c|c|c|c|c|c|c|}
\hline \multirow{11}{*}{ 岕 } & \multicolumn{9}{|c|}{ Distribution of major constituents in bed-sediments } \\
\hline & Value & \multicolumn{2}{|l|}{$\begin{array}{c}\mathrm{CaCO}_{3} \\
\%\end{array}$} & $\begin{array}{c}\text { TOC } \\
\%\end{array}$ & \multicolumn{2}{|l|}{$\begin{array}{c}\mathbf{F e}_{2} \mathbf{O}_{3} \\
\%\end{array}$} & $\begin{array}{c}\mathbf{T i O}_{2} \\
\%\end{array}$ & \multicolumn{2}{|r|}{$\underset{\%}{\mathrm{MnO}}$} \\
\hline & $\min$ & 9,83 & \multicolumn{2}{|r|}{3,02} & \multicolumn{2}{|l|}{2,14} & 0,18 & \multicolumn{2}{|r|}{0,059} \\
\hline & $\max$ & 49,89 & \multicolumn{2}{|r|}{6,5} & \multicolumn{2}{|l|}{4,09} & 0,85 & \multicolumn{2}{|r|}{0,092} \\
\hline & mean & 32,79 & \multicolumn{2}{|r|}{4,98} & \multicolumn{2}{|l|}{2,81} & 0,40 & \multicolumn{2}{|r|}{0,08} \\
\hline & \multicolumn{9}{|c|}{ Distribution of heavy metals in bed-sediments } \\
\hline & Value & $\mathbf{Z n}$ & $\begin{array}{c}\mathbf{N i} \\
\mu \mathrm{g} / \mathrm{g}\end{array}$ & $\mathrm{Cr}$ & $\mathbf{V}$ & Co & $\mathbf{P b}$ & $\mathrm{Cu}$ & $\mathbf{C d}$ \\
\hline & & $\mu \mathrm{g} / \mathrm{g}$ & $\mu \mathrm{g} / \mathrm{g}$ & $\mu \mathrm{g} / \mathrm{g}$ & & $\mu \mathrm{g} / \mathrm{g}$ & $\mu \mathrm{g} / \mathrm{g}$ & $\mu \mathrm{g} / \mathrm{g}$ & $\mu \mathrm{g} / \mathrm{g}$ \\
\hline & $\min$ & 31,2 & 18,2 & 21,5 & 20 & 2,44 & 7,51 & 12,99 & 0,109 \\
\hline & $\max$ & 47,3 & 25 & 56,6 & 97 & 6,57 & 13,24 & 25,23 & 0,152 \\
\hline & mean & 39,90 & 22,38 & 33,33 & 47,75 & 4,14 & 10,15 & 18,63 & 0,13 \\
\hline & & istribution & of the & he main lith & $\operatorname{logical~p}$ & amete & in bed & edimen & \\
\hline & Value & TOM & & CAR & SIL & & $\mathbf{W C}$ & & $\overline{D M}$ \\
\hline & & $\%$ & & $\%$ & $\%$ & & $\%$ & & $\%$ \\
\hline & $\min$ & 24,11 & & 0,11 & 1,34 & & 12,89 & & 77,65 \\
\hline & $\max$ & 98,55 & & 13,10 & 63,76 & & 22,35 & & 87,11 \\
\hline & mean & 84,27 & & 5,91 & 9,82 & & 18,54 & & 81,46 \\
\hline & & Dist & tibution & on of major & constitue & ts in $b$ & 1-sedim & & \\
\hline$\stackrel{5}{=}$ & Value & $\mathrm{CaCO}_{3}$ & & TOC & $\mathrm{Fe}_{2} \mathrm{O}_{3}$ & & $\mathrm{TiO}_{2}$ & & MnO \\
\hline 国 & & $\%$ & & $\%$ & $\%$ & & $\%$ & & $\%$ \\
\hline $\bar{z}$ & $\min$ & 13,95 & & 1,19 & 1,83 & & 0,12 & & 0,056 \\
\hline 煎 & $\max$ & 35,56 & & 7,13 & 3,48 & & 0,62 & & 0,094 \\
\hline$\sum$ & mean & 24,35 & & 5,51 & 2,46 & & 0,32 & & 0,07 \\
\hline & & & istribut & ution of hea & y metals & in bed- & ediment & & \\
\hline & Value & $\mathbf{Z n}$ & $\mathbf{N i}$ & $\mathrm{Cr}$ & V & Co & $\mathbf{P b}$ & $\mathrm{Cu}$ & Cd \\
\hline & & $\mu \mathrm{g} / \mathrm{g}$ & $\mu \mathrm{g} / \mathrm{g}$ & $\mu \mathrm{g} / \mathrm{g}$ & $\mu \mathrm{g} / \mathrm{g}$ & $\mu \mathrm{g} / \mathrm{g}$ & $\mu \mathrm{g} / \mathrm{g}$ & $\mu \mathrm{g} / \mathrm{g}$ & $\mu \mathrm{g} / \mathrm{g}$ \\
\hline & $\min$ & 22,9 & 13,7 & 19,9 & 14 & 1,35 & 4,28 & 9,1 & 0,053 \\
\hline & $\max$ & 47,1 & 34,8 & 52,4 & 79 & 8,18 & 15,39 & 16,61 & 0,238 \\
\hline & mean & 32,36 & 20,84 & 28,78 & 39,20 & 3,78 & 8,96 & 12,30 & 0,12 \\
\hline & & stributiol & of the & ne main lith & $\operatorname{logical} \mathrm{p}$ & aramete & in bed & edimen & \\
\hline & Value & TOM & & $\overline{\text { CAR }}$ & SIL & & WC & & $\overline{D M}$ \\
\hline & & $\%$ & & $\%$ & $\%$ & & $\%$ & & $\%$ \\
\hline & $\min$ & 60,46 & & 1,46 & 6,07 & & 11,30 & & 68,49 \\
\hline & $\max$ & 88,62 & & 15,37 & 34,93 & & 31,51 & & 88,70 \\
\hline & mean & 79,77 & & 8,32 & 11,90 & & 19,97 & & 80,03 \\
\hline & & Dist & ribution & on of major & constitue & tts in $b$ & 1-sedim & & \\
\hline 変 & Value & $\mathrm{CaCO}_{3}$ & & TOC & $\mathbf{F e}_{2} \mathbf{O}_{3}$ & & $\mathbf{T i O}_{2}$ & & MnO \\
\hline 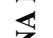 & & $\%$ & & $\%$ & $\%$ & & $\%$ & & $\%$ \\
\hline Z & $\min$ & 8,5 & & 3,25 & 2,52 & & 0,21 & & 0,047 \\
\hline है & $\max$ & 39,43 & & 7,36 & 6,15 & & 0,94 & & 0,132 \\
\hline 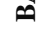 & mean & 19,31 & & 5,95 & 4,33 & & 0,56 & & 0,09 \\
\hline & & & istribut & ution of hea & y metals & in bed- & ediment & & \\
\hline & Value & $\begin{array}{c}\mathrm{Zn} \\
\mu \mathrm{g} / \mathrm{g}\end{array}$ & $\begin{array}{c}\mathrm{Ni} \\
\mu \mathrm{g} / \mathrm{g}\end{array}$ & $\begin{array}{c}\mathrm{Cr} \\
\mu \mathrm{g} / \mathrm{g}\end{array}$ & $\begin{array}{c}\mathrm{V} \\
\mu \mathrm{g} / \mathrm{g}\end{array}$ & $\begin{array}{c}\mathrm{Co} \\
\mu \mathrm{g} / \mathrm{g}\end{array}$ & $\begin{array}{c}\mathrm{Pb} \\
\mu \mathrm{g} / \mathrm{g}\end{array}$ & $\begin{array}{c}\mathrm{Cu} \\
\mu \mathrm{g} / \mathrm{g}\end{array}$ & $\begin{array}{c}\mathrm{Cd} \\
\mu \mathrm{g} / \mathrm{g}\end{array}$ \\
\hline & $\min$ & 45,4 & 28,3 & 27,1 & 19 & 3,73 & 10 & 26,38 & 0,236 \\
\hline & $\max$ & 110,2 & 49 & 116,8 & 111 & 13,36 & 19,17 & 51,29 & 0,72 \\
\hline & mean & 72,84 & 37,58 & 83,72 & 81,80 & 8,14 & 13,69 & 37,54 & 0,41 \\
\hline
\end{tabular}

Withal, the CAR (\%) content showed higher mean concentrations, over $1 \%$ of the total weight of dry sediment, as in the Matita Lake (16.68 \%) and Babina Lake (8.32 $\%$ ), while the lowest mean value was recorded in Merhei Lake (5.91\%). What remains 


\section{INTERNATIONAL SYMPOSIUM "THE ENVIRONMENT AND THE INDUSTRY", SIMI 2017, PROCEEDINGS BOOK}

is attributed to SIL (\%) fraction, that showed higher mean concentration in Matita Lake $(20.84 \%)$ and Babina Lake $(11.90 \%)$, while the lowest mean value was reported in Mehei Lake (9.82\%). On the basis of the obtained results it can be asserted that the sedimentary accumulations of these recent sediments within the three ecological sites (i.e., Matita, Merhei and Babina) belong to the category of organic sediments (rich and very rich in organic matter), subsequently followed by organic-mineral sediments, and a noticeable higher carbonate content, too. The results mentioned in Table 2 show the concentration of the major constituents and heavy metals in bed-sediment samples collected from three lakes. Generally, the technophyllic heavy metal concentrations $(\mathrm{Ni}, \mathrm{Cu}, \mathrm{Pb}, \mathrm{Zn}$ and $\mathrm{Cd})$ of the bed-sediments were below the limits of the quality criteria. The exceptions were represented by local values, incidentally exceeding the recommended limit. So, $\mathrm{Ni}, \mathrm{Cu}, \mathrm{Pb}, \mathrm{Zn}$ and $\mathrm{Cd}$ exhibited the highest mean concentration in Babina Lake $(37.58 \mu \mathrm{g} / \mathrm{g}, 37.54 \mu \mathrm{g} / \mathrm{g}, 13.69 \mu \mathrm{g} / \mathrm{g}, 72.84 \mu \mathrm{g} / \mathrm{g}$ and respectively $0.41 \mu \mathrm{g} / \mathrm{g})$ and Matita Lake $(22.38 \mu \mathrm{g} / \mathrm{g}, 18.63 \mu \mathrm{g} / \mathrm{g}, 10.15 \mu \mathrm{g} / \mathrm{g}, 39.9$ $\mu \mathrm{g} / \mathrm{g}$ and respectively $0.13 \mu \mathrm{g} / \mathrm{g})$, while the lowest mean value was recorded in bedsediments collected from Merhei Lake $(20.84 \mu \mathrm{g} / \mathrm{g}, 12.3 \mu \mathrm{g} / \mathrm{g}, 8.96 \mu \mathrm{g} / \mathrm{g}, 32.36 \mu \mathrm{g} / \mathrm{g}$ and respectively $0.12 \mu \mathrm{g} / \mathrm{g}$ ).

\section{Conclusions}

The water and sediment quality deterioration is one of the most important environmental challenges currently facing around the world, originated mainly by several types of anthropogenic sources. This study shows that Matita, Merhei and Babina Lakes's water exhibit overall, normal values for oxygen content, electrical conductivity levels, total dissolved solids concentration, sulphates content, total suspended solids and silica content. Slightly $\mathrm{pH}$ elevated values indicate the slightly alkaline character of lacustrine water. The analysis shows that turbidity, nitrite nitrogen and orthophosphates were above the permissible limits in some investigated water samples. Probably, the slightly elevated turbidity values in some water samples and for a short period of time not be significant. Generally, increases in nitrate and phosphate levels can affect the algae blooms. Causes of water quality impairment may be due to inorganic nitrogen and phosphorus from anthropogenic sources (i.e., fertilizer run-off) or, as a result of nutrient dynamics in lakes (remobilisation of nitrogen and phosphorus from lacustrine sediments).

Like freshwater, the aquatic sediments are an important natural resource, constituting an important compartment in the energy flux (bio-geo-chemical cycle) of aquatic ecosystems, but their quality could be impaired by several anthropogenic activities. The complex nature of lacustrine deposits is a result of numerous sediment sources originated from autochthonous (in-lake processes) and allochthons input, and different depositional and post-depositional processes generated by natural or humanrelated factors. The lithological analysis allowed to reveal a category of organic sediments (rich and very rich in organic matter), subsequently followed by organicmineral sediments, and a noticeable higher carbonate content, too. Probably, the inlake hydro-sedimentological processes of these standing waters have a considerable role in terms of the influx of autochthonous material contrary to allochthons material. Sediment quality has been acknowledged as an important indicator of water contamination. Sediments act as a repository and a source of contaminants (i.e., heavy metals) in the aquatic environment, having a role in the migration and retention of potentially hazardous materials. The concentration of technophyllic heavy metals in 


\section{INTERNATIONAL SYMPOSIUM "THE ENVIRONMENT AND THE INDUSTRY", SIMI 2017, PROCEEDINGS BOOK}

the bed-sediments of different ecological sites from Matita-Merhei Depression were below the limits of the quality criteria. The exceptions were represented by local values, incidentally exceeding the recommended limit. The fluctuations encountered within this investigation are most likely due to local hydro-sedimentological actual conditions of three ecological sites as, sampling stations, seasonal changes in the water budget through hydrological network etc. that impact incidentally the water and sediment conventional variables. Generally speaking, it should not be omitted either the siltation process that constitutes one of the most important problems in deltaic lakes that could also be responsible for the degradation of the water and sediment lake's quality. Favourable conditions such as the position of lakes in the Danube Delta, high alluvial content, water regime of the Danube River, morpho-hydrographic conditions, abundant aquatic vegetation, include the danubian lakes in the category of lakes susceptible to progressive colmatation (long-term changes in the delta).

\section{Acknowledgements}

The research leading to these results was financed from the Romanian National Authority for Scientific Research and Innovation - ANCSI -"Program Nucleu 37N/2016 - PN 164501 04".

\section{References}

Black, CA 1965, Methods of soil analysis, America. Society of Agronomy, Monograph 9 Madison, Wisconsin.

Bondar, C \& Panin, N 2001, 'The Danube Delta Hydrologic database and modeling', GeoEcoMarina, vol 5-6, pp 5-52.

De Bakker, H \& Schelling J 1989, Systeem van bodemclassificatie voor Nederland: de hogere niveaus, 2nd edition, Centre for Agricultural Publishing and Documentation, Wageningen.

Dean, WE 1974, 'Determination of carbonate and organic matter in calcareous sediments and sedimentary rocks by loss on ignition: comparison with other methods', Journal of Sedimentary Petrology, vol.44, pp 242-248.

Gastescu, P \& Stiuca, R 2008, Delta Dunarii. Rezervatie a biosferei The Danube Delta - A Biosphere Reserve, CD Press Publishing House, Bucharest, [in Romanian].

Gaudette, HE, Flight, WR, Toner, L \& Folger DW 1974, 'An inexpensive titration method for the determination of organic carbon in recent sediments', Journal of Sedimentary Petrology, vol.44, pp 249-253.

Heiri O, Lotter A F \& Lemcke G, 2001, 'Loss on ignition as a method for estimating organic and carbonate content in sediments: reproducibility and comparability of results', Journal of Paleolimnology, vol 25, pp 101-110.

Panin, N 1996, 'Danube Delta: Genesis, evolution, geological setting and sedimentology', GeoEco-Marina, vol 1, pp 7-23.

Santisteban, JI, Mediavilla, R, Lopez-Pamo, E, Dabrio, CJ, Ruiz Zapata, MB, Garcia, MJ, Castano, S \& Martinez-Alfaro, PE 2004, 'Loss on ignition: a qualitative or quantitative method for organic matter and carbonate mineral content in sediments', Journal of Paleolimnology, vol 32, pp 287-299.

van der Veer, G 2006, Geochemical soil survey of the Netherlands, NGS 347. 